\title{
Thalidomide-Rituximab Regimen
}

National Cancer Institute

\section{Source}

National Cancer Institute. Thalidomide-Rituximab Regimen. NCI Thesaurus. Code C63466.

A regimen consisting of thalidomide and rituximab used to treat relapsed or refractory mantle cell lymphoma. 